\title{
SOME ASPECTS OF RACCOON DOG'S (NYCTEREUTES PROCYONOIDES GRAY, 1834) FOOD BEHAVIOR IN DEPEND ON DEPTH OF SNOW COVER ON THE FLOODPLAIN TERRITORY OF NATIONAL PARK «SAMARSKAYA LUKA»
} (C) 2016

\author{
V.V. Martynova, postgraduate student of the Chair of Ecology, Botany and Nature Protection \\ Samara National Research University, Samara (Russia)
}

\begin{abstract}
The raccoon dog, which is inhabit the territory of national park «Samarskaya Luka», considered an invasive species with the high ecological plasticity. It has been acclimatized successfully and still continues to expand its range. Taking into account this fact, it is particularly relevant to reveal some aspects of its behavior. The important point is the adaptation of the species in the conditions of anthropogenic press, which are observed in the national park's territory. The studies was carried out on the riparian territories of the national park «Samarskaya Luka» (village Mordovo and village Malaya Ryazan), because the raccoon dog tends to inhabit the floodplain areas, river banks, islands and channels, and avoid large open fields. The research object is the raccoon dogs' population on riparian territories of the national park. The study was carried out by detailed winter footprints tracking method. The article presents data on the weather's severity conditions, Bodman index was calculated for the areas of tracking in the study period. The data compared detailed winter tracking in the snowy (2012) and snowless (2013) research period materials are presented. The obtained data illustrate differences in research, food and food searching behavioral activity of raccoon dog's males and females depending on the depth of the snow cover and weather conditions. The results are consistent with the literature data on the weather's severity in the Samara region and changes of canids behavior's in different seasons. The data obtained can be used by staff of specially protected natural areas, forestry and hunting organizations for introduced species' population monitoring.

Keywords: raccoon dog; Nyctereutes procyonoides; introduced species; canids; food behavior; food searching behavior; behavioral activity; anthropogenic press; adaptation; snow cover; Bodman index; special protected natural areas; Samara region; floodplain areas.
\end{abstract}

УДК 579.69

\section{ВЛИЯНИЕ ТЕМПЕРАТУРЫ И ИСТОЧНИКОВ УГЛЕРОДА НА БИОСИНТЕЗ АУКСИНА ШТАММОМ RHODOCOCCUS ERYTHROPOLIS BКМ AC-2017D И ЕГО ФИТОСТИМУЛИРУЮЩАЯ АКТИВНОСТЬ В ПОЧВЕННЫХ УСЛОВИЯХ} (C) 2016

\section{Д.Н. Отрошко, аспирант кафедры генетики, микробиологии и биотехнологии}

B.B. Шеремет, магистрант биологического факультета

Н.Н. Волченко, кандидат биологических наук, доцент кафедры генетики, микробиологии и биотехнологии А.А. Худокормов, кандидат биологических наук, доцент кафедры генетики, микробиологии и биотехнологии А.А. Самков, кандидат биологических наук, преподаватель кафедры генетики, микробиологии и биотехнологии Кубанский государственный университет, Краснодар (Россия)

Аннотация. Целью исследования было изучение влияния температуры и источников углерода на способность к синтезу индолил-три-уксусной кислоты (ИУК) штамма Rhodococcus erythropolis BKM Ac-2017D на минеральной среде с добавлением в качестве предшественника триптофана в концентрации 0,5 г/л. Фитостимулирующий эффект был показан в почвенном эксперименте с применением газонной травосмеси (Festuca rubra $-30 \%$, Lolium perenne $-30 \%$, Poa pratensis $-20 \%$, Festuca rubra trichlorophylla $-15 \%$, Festuca ovina 5\%). Штамм-деструктор нефтепродуктов Rhodococcus erythropolis BKM Ac-2017D был способен к продукции фитогормона ауксина как на гексадекане, так и на сахарозе. Обнаружены различия в продукции ауксина при температурах $\left(15,25,35^{\circ} \mathrm{C}\right)$ и на разных типах углеродных субстратов. Если источником углерода выступала сахароза, то максимальная продукция фитогормона в 34,4 мкг/мл наблюдалась при температуре $15^{\circ} \mathrm{C}$. При культивировании микроорганизмов на гексадекане максимальный выход индолил-3-уксусной кислоты был отмечен при температуре $25^{\circ} \mathrm{C}$, он составил 77,69 мкг/мл. В полевом эксперименте было продемонстрировано, что максимальной фитостимулирующей активностью по отношению к газонной траве в условиях урбанозёма обладали супернатант, содержащий экзометаболиты исследуемого микроорганизма, и нативная жидкая культура - они в несколько раз увеличивали сырую фитомассу и всхожесть газонной травы относительно обработки водой и химически синтезированной ИУК.

Ключевые слова: индолил-3-уксусная кислота (ИУК); растительно-микробные взаимодействия; нефтеокисляющие бактерии; Rhodococcus erythropolis; стимулирующие рост растений бактерии (PGPB); ризосфера; всхожесть растений; фитостимуляция; ризоремедиация; экологическая микробиология и биотехнология.

В настоящее время существует тенденция к росту антропогенного влияния на экосистемы. К наиболее распространённым поллютантам относятся нефтя- ные, полициклические ароматические, галогенированые углеводороды, пестициды, растворители, тяжелые металлы и их соли. Попадая во внешнюю среду, 
они способны негативно влиять на состояние здоровья людей [1]. Одной из перспективных технологи очистки антропогенно нарушенных почв является технология ризоремедиации [2], суть которой сводится к совместному использованию потенциала бактерий и растений для снижения уровня токсических органических соединений во внешней среде [3]. К настоящему моменту известно, что основную роль в окислении поллютантов выполняет микрофлора ризосферы, обладающая ростстимулирующими свойствами - например, способностью к фиксации атмосферного азота, растворению неорганических фосфатных солей, синтезу сидерофоров и фитогормонов. Группа бактерий, обладающая данными качествами, получила название PGPR (plant growth promoting rhizobacteria). Как правило, данные микроорганизмы не обладают способностью разрушать устойчивые органические поллютанты, поэтому для реализации технологии ризоремедиации разрабатывают либо генетически-модифицированные штаммы микроорганизмов, которые обладают набором необходимых признаков [4], либо производят скрининг бактерий на наличие требуемых физиолого-биохимических качеств $[5 ; 6]$. Одним из важнейших механизмов положительного влияния на развитие растений является синтез фитогормонов [7-9], в том числе индолилуксусной кислоты и её производных. Кроме положительного эффекта на жизнедеятельность растений экзогенная индолил-3-уксусная кислота способна также оказывать воздействие на ферментативную активность почв и на прирост бактериальной биомассы [10].

Поэтому особо актуальным является вопрос о подборе микроорганизмов и растений для проведения биологической очистки почвы от токсичных химических соединений. Наиболее часто в технологии ризоремедиации используются представители рода Pseudomonas, но потенциально перспективными являются представители р. Rhodococcus. Так, инокуляция почвы штаммом Rhodococcus erythropolis P30 способствовала экстракции тяжелых металлов растениями из среды [11]. Успешная реализация ризоремедиации зависит и от выживания и роста растений на загрязненных участках, а также от способности их корней поддерживать активность микробного населения почвы [12]. Для повышения скорости ризоремедиации используются толерантные виды растений с быстрым ростом и мощной корневой системой [13].

Целью настоящей работы было изучение влияние температуры и источников углерода на биосинтез индолил-3-уксусной кислоты штаммом Rhodococcus erythropolis BKM Ac-2017D, выявление фитостимулирующей активности данного микроорганизма в условиях почвенного эксперимента. Rhodococcus erythropolis BKM Ac-2017D был выделен сотрудниками кафедры генетики, микробиологии и биотехнологии Кубанского государственного университета и ранее был успешно использован в технологии биоремедиации загрязненного нефтью грунта [14-16].

Для культивирования микроорганизмов использовали стандартную минеральную среду следующего состава (Г/л): $\mathrm{KNO}_{3}-4 ; \mathrm{Na}_{2} \mathrm{HPO}_{4}-1,4 ; \mathrm{KH}_{2} \mathrm{PO}_{4}-0,4$; $\mathrm{MgSO}_{4} \times \mathrm{H}_{2} \mathrm{O}-0,8$ [17]. С целью оценки влияния температуры среды на выход фитогормона Rhodococcus erythropolis ВКМ Ac-2017D культивировался при разных $\left(15,25,35^{\circ} \mathrm{C}\right)$ температурах. В качестве источников углерода в среде использовали сахарозу и гексадекан, в концентрациях 10 г/л. В качестве вещества-предшественника в биосинтезе ауксина использовали триптофан, в концентрации 0,5 г/л.

Для обнаружения в культуральной жидкости ауксина и определения его концентрации проводили реакцию Сальковского на индолилуксусную кислоту и её производные. Согласно методике [18], к супернатанту добавляли реактив $\left(0,05 \mathrm{M} \mathrm{FeCl}_{3}\right.$ в $37 \%$ раствоpe хлорной кислоты $\left.\mathrm{HClO}_{4}\right)$, после прохождения цветной реакции концентрацию ИУК определяли фотометрически по калибровочному графику, изображенному на рис. 1.

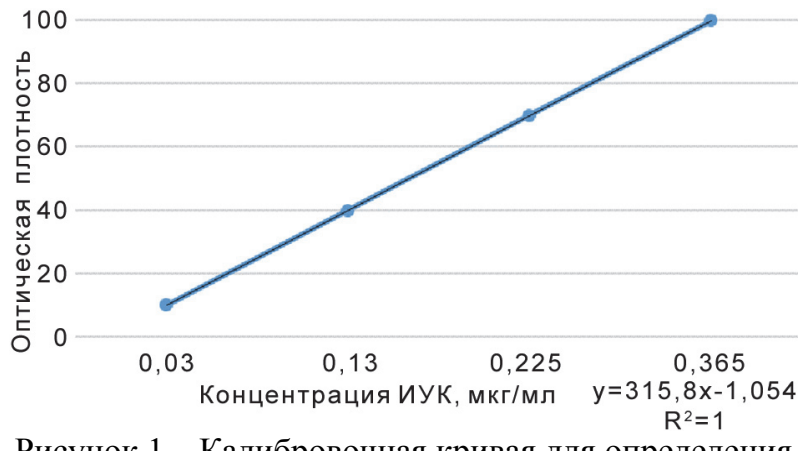

Рисунок 1 - Калибровочная кривая для определения концентрации ИУК в среде

Фитостимулирующий эффект был показан в почвенном эксперименте с применением газонной травосмеси (Festuca rubra - 30\%, Lolium perenne - 30\%, Poa pratensis - 20\%, Festuca rubra trichlorophylla $15 \%$, Festuca ovina - 5\%). Для учета общего микробного числа (ОМЧ) использовали метод высева из серийных разведений на питательный агар.

Физиологические особенности бактерий вида Rhodococcus erythropolis позволяет представителям данного вида развиваться в относительно широком диапазоне температур, сохраняя при этом свои метаболические возможности. Обнаружены различия в продукции ауксина при разных температурах на разных типах углеродных субстратах. Если источником углерода выступал сахароза, то максимальная продукция фитогормона 34,4 мкг/мл наблюдалась при температуре $15^{\circ} \mathrm{C}$ (табл. 1). Тогда как при 25 и $35^{\circ} \mathrm{C}$ значения статистически не отличались и составляли 19,8 и 16,1 мкг/мл соответственно. Данные различия в количестве синтезируемого фитогормона могут быть связаны с особенностями жизнедеятельности родококков, открывая возможность применения данного штамма как фитостимулятора в психрофильных условиях. Это не противоречит имеющимся в литературе сведениям о том, что при низких температурах наблюдается увеличение физиолого-биохимической активности данных микроорганизмов [19].

Таблица 1 - Влияние температуры и источников углерода на биосинтез ИУК Rhodococcus erythropolis B2

\begin{tabular}{|c|c|c|c|}
\hline \multirow{2}{*}{$\begin{array}{c}\text { Источник } \\
\text { углерода }\end{array}$} & \multicolumn{3}{|c|}{$\begin{array}{c}\text { Концентрация ИУК при различных } \\
\text { температурах, мкг/мл }\end{array}$} \\
\hline & $15^{\circ} \mathrm{C}$ & $25^{\circ} \mathrm{C}$ & $35^{\circ} \mathrm{C}$ \\
\hline Caxa & $34,42 \pm 0,95 *$ & $19,8 \pm 1,33$ & $16,1 \pm 1,25$ \\
\hline Гексадекан & $49,47 \pm 4,00$ & $77,69 \pm 6,81^{*}$ & $46,42 \pm 4,45$ \\
\hline
\end{tabular}


При культивировании микроорганизмов на гексадекане максимальный выход фитогормона отмечен при температуре $25^{\circ} \mathrm{C}$, и он составил 77,69 мкг/мл. Можно предположить, что данная картина обусловлена отчасти слабой проницаемостью гексадекана как гидрофобного углеводорода в клетки при его температуре плавления менее $18^{\circ} \mathrm{C}$ и его деструктивными эффектами как неполярного растворителя для мембран бактерий при повышении температуры до $35^{\circ} \mathrm{C}$. В литературных источниках имеются сведения о том, что ризосферные псевдомонады способны синтезировать максимальные количества ИУК в концентрации 70 мкг/мл при температуре в диапазоне 26-28 ${ }^{\circ} \mathrm{C}$ [20], сравнительных данных по родоккам не известно. К ИУК в культуральную жидкость может приводить изменение в химическом строении клеточных мембран. К переменам в составе миколовых кислот в мембранах клеток бактерий приводят используемые источники углерода, что отражается на проницаемости мембраны клеток бактерий [21]. Исходя из полученных данных, можно сделать вывод, что родококки, обладая набором физиолого-биохимических характеристик, способны лучше адаптироваться к изменению условий окружающей среды, что дает им преимущество в условиях стресса. В целом показано, что исследуемый штамм способен к продукции фитогормона в присутствии не только углеводородных поллютантов, но и на углеводах, которые могут поступать в почву с корневыми экссудатами растений.

Оценку фитостимулирующих свойств штамма бактерии Rhodococcus erythropolis BKM Ac-2017D проводили в полевом эксперименте - в почвенных условиях урбанозёма с высевом газонной травосмеси. На территории Кубанского государственного университета были заложены 5 площадок размером по $0,1 \mathrm{M}^{2}$, на участке урбанозёма с отсутствующей естественной растительностью. Каждая из них засевалась газонной травой и обрабатывалась индивидуально биологическим или химическим агентом каждые 5 дней в течение 20 суток. Участок № 1 - культуральная жидкость, отобранная как супернатант после центрифугирования исходной жидкой культуры; № 2 - биомасса клеток, осажденная ценрифугированием; № 3 - нативная жидкая культура (ЖК) исследуемого штамма; № 4 - раствор химически синтезированной ИУК, равный по концентрации содержанию ИУК в бесклеточной жидкости (50 мг/л); № 5 контроль (соответствующий объем воды) (рис. 2).

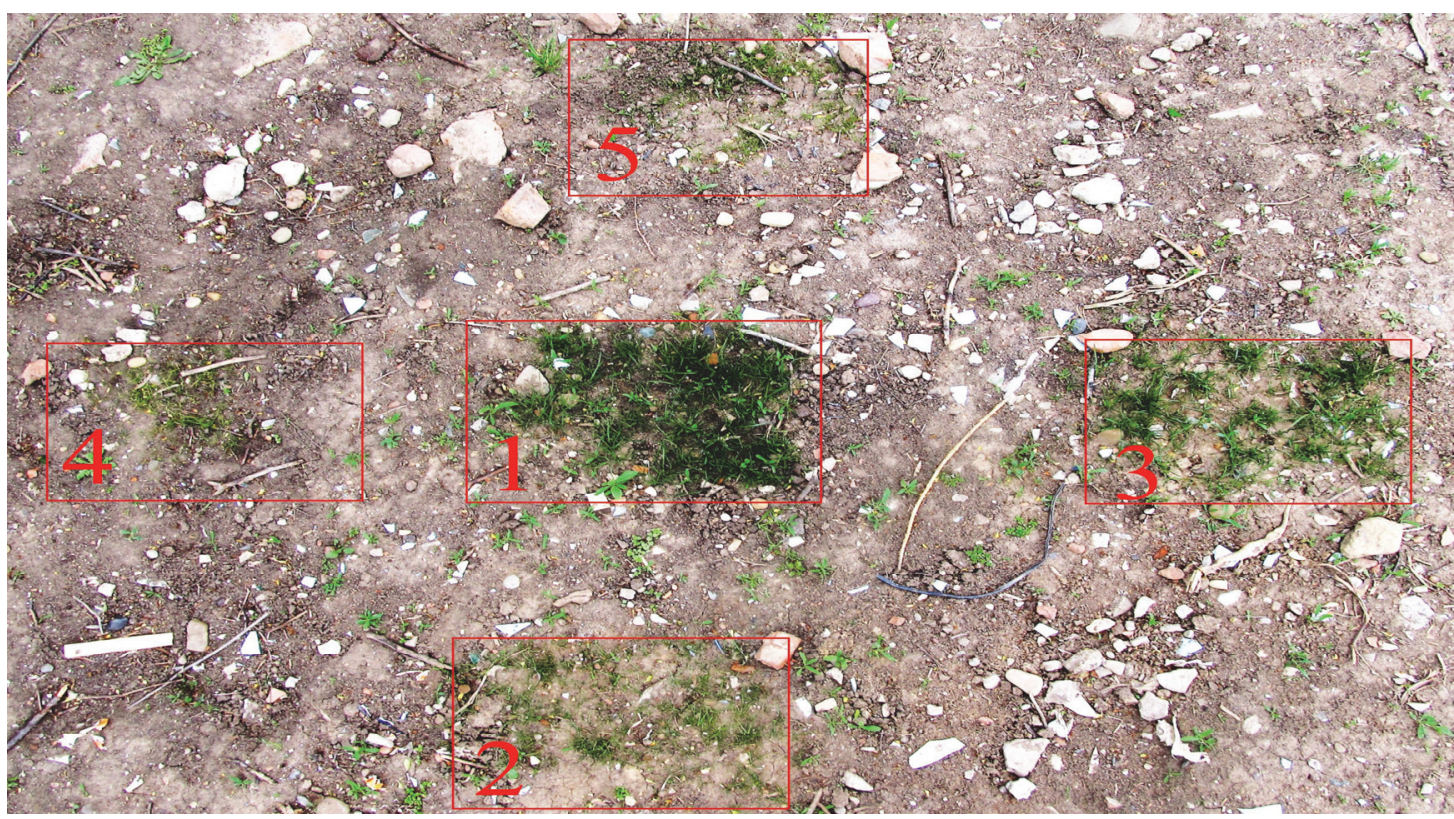

Рисунок 2 - Фотография полевых участков и варианты обработки биологическими и химическими агентами

Фитостимулирующие свойства оценивали по 3 показателям - сырой фитомассе, динамике всхожести газонной травы и концентрации микроорганизмов в почве.

К 20 суткам эксперимента был произведен замер сырой массы побегов, которая количественно отражает развитие растений. Данный показатель часто используют при характеристике штаммов микроорганизмов, которые в перспективе могут быть использованы как основа биопрепарата [22].

Ввиду того, что субстрат, освещённость и влажность на всех площадках были одинаковыми, различия массы всходов на момент окончания эксперимента - показатель влияния вносимых агентов. Газонная трава, обработанная культуральной жидкостью с клетками и без клеток, демонстрировала выход фитомассы более 100 г/M². В свою очередь участок с газоном, в который вносились суспендирован- ные клетки, имел массу до 20 г/м² (рис. 3). Это говорит о решающем значении внеклеточных метаболитов исследуемого микроорганизма при оценке его фитостимулирующих свойств. Однако роль ИУК неоднозначна, так как участок, который обрабатывался химически полученным фитогормоном, схожих результатов не показал. Вероятно, метаболиты бактерии Rhodococcus erythropolis BKM Ac-2017D содержат дополнительные факторы, оказывающие прямое или опосредованное влияние на растения.

К 20 суткам было отмечено влияние исследуемого микроорганизма на всхожесть. На контрольном участке всхожесть принята за $100 \%$. Раствор химически синтезированной ИУК показал результат ниже контрольного. Площадки, обработанные клетками или метаболитами Rhodococcus erythropolis BКМ Ac2017D (рис. 4), значительно превосходили контроли. 

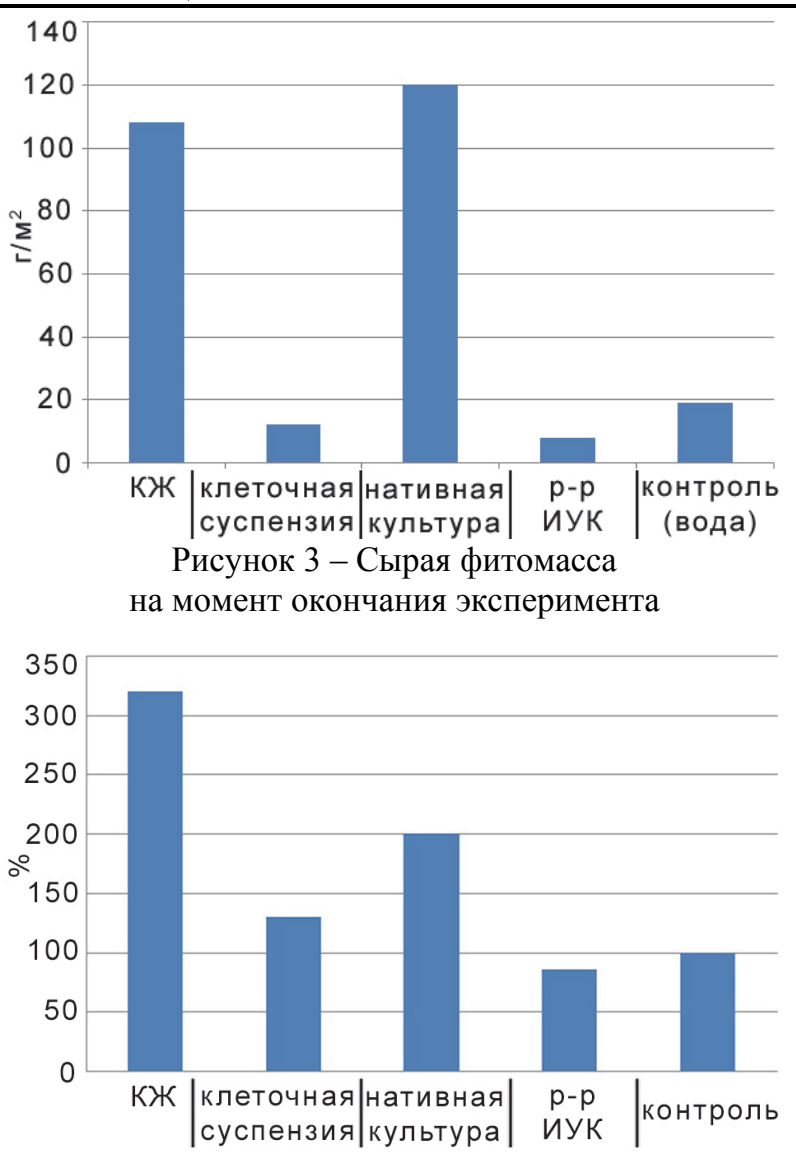

Рисунок 4 - Динамика всхожести газонной травы в течение эксперимента

Для оценки микробиологической активности урбанозёма, а также оценки её динамики в ходе эксперимента был произведён учёт данных по общему микробному числу (ОМЧ) гетеротрофных аэробных микроорганизмов в 1 г почвы. Результаты этих исследований отражены в таблице 2.

Таблица 2 - Динамика ОМЧ (КОЕ/г почвы) на полевых участках

\begin{tabular}{|c|c|c|c|c|c|}
\hline $\begin{array}{c}\text { Сут- } \\
\text { ки }\end{array}$ & КЖ & $\begin{array}{c}\text { Клеточная } \\
\text { суспензия }\end{array}$ & $\begin{array}{c}\text { Нативная } \\
\text { культура }\end{array}$ & $\begin{array}{c}\text { Раствор } \\
\text { ИУК }\end{array}$ & Вода \\
\hline 5 & $4,9 \times 10^{5}$ & $3,4 \times 10^{5}$ & $6,1 \times 10^{5}$ & $2,6 \times 10^{5}$ & $2,7 \times 10^{5}$ \\
\hline 15 & $1,4 \times 10^{6}$ & $2,6 \times 10^{6}$ & $9,6 \times 10^{6}$ & $8 \times 10^{5}$ & $1,5 \times 10^{6}$ \\
\hline 25 & $2,1 \times 10^{8}$ & $1,2 \times 10^{8}$ & $10^{8}$ & $2,8 \times 10^{7}$ & $5,9 \times 10^{6}$ \\
\hline
\end{tabular}

Как видно, через 5 суток после обработки отсутствовал заметный эффект по влиянию на концентрацию микроорганизмов в почве - на всех участках она составляла $10^{5} \mathrm{KOE} / г$, колеблясь внутри порядка от $(2,6$ до 6,1$) \times 10^{5}$. К 15 -м суткам ОМЧ увеличилось во всех образцах, кроме обработанного раствором ИУК до $10^{6}$ КОЕ/г. К 25-м суткам опыта на всех участках, обработанных биологическими агентами на основе нефтеокисляющего родококка, концентрация клеток составила $(1-2,1) \times 10^{8} \mathrm{KOE} / г$, что на 2 порядка превышало контроль с обработанной водой и на 1 порядок - обработанный химически синтезированной ИУК. Можно отметить, что биологическая обработка родококком оказала стимулирующий эффект не только на ростовые характеристики растений, но и на общую микробиологическую активность почвы.

Bblвoдbl. В результате проведённого эксперимента показано, что штамм-деструктор нефтепродуктов
Rhodococcus erythropolis BKM Ac-2017D способен к продукции фитогормона ауксина как на углеводородном, так и на углеводном источнике углерода. Это открывает возможность комплексного использования данного микроорганизма в качестве продуцента фитогормона как на основе нефтепродуктовполлютантов почв, так и на углеводных выделениях корневых экссудатов растений-фиторемедиантов. Температурная зависимость продукции имела разный характер - на сахарозе максимальный выход в 34,3 мкг/мл при $15^{\circ} \mathrm{C}$ и на гексадекане 82,95 мкг/мл при $25^{\circ} \mathrm{C}$.

В полевом эксперименте показано, что максимальной фитостимулирующей активностью по отношению к газонной траве в условиях урбанозёма обладали супернатант и нативная жидкая культура штамма Rhodococcus erythropolis BKM Ac-2017D. Они в несколько раз увеличивали сырую фитомассу и всхожесть газонной травы относительно обработки водой и химически синтезированной ИУК. Аналогично была повышена на 1-2 порядка и численность аэробной гетеротрофной микрофлоры в почве при обработке цельной жидкой культурой родококка, а также культуральной жидкостью и биомассой клеток на её основе. Также обработка родококком оказала положительный эффект на общую микробиологическую активность почвы, которая является важным показателем восстановления нарушенной экосистемы.

\section{СПИСОК ЛИТЕРАТУРЫ:}

1. Kim K.H., Jahan S.A., Kabir E., Brown R.J.C. A review of airborne polycyclic aromatic hydrocarbons (PAHs) and their human health effects // Environment international. 2013. Vol. 60. P. 71-80.

2. Gerhardt K.E., Huang X.D., Glick B.R., Greenberg B.M. Phytoremediation and rhizoremediation of organic soil contaminants: potential and challenges // Plant Science. 2009. Vol. 176. № 1. P. 20-30.

3. Kuiper I., Lagendijk E.L., Bloemberg G.V., Lugtenberg B.J.J. Rhizoremediation: a beneficial plantmicrobe interaction // Molecular Plant-Microbe Interactions. 2004. Vol. 17. № 1. P. 6-15.

4. de Cárcer D.A., Martín M., Mackova M., Macek T., Karlson U., Rivilla R. The introduction of genetically modified microorganisms designed for rhizoremediation induces changes on native bacteria in the rhizosphere but not in the surrounding soil // The ISME journal. 2007. Vol. 1. № 3. P. 215-223.

5. Ontañon O.M., González P.S., Ambrosio L.F., Paisio C.E., Agostini E. Rhizoremediation of phenol and chromium by the synergistic combination of a native bacterial strain and Brassica napus hairy roots // International Biodeterioration \& Biodegradation. 2014. Vol. 88. P. 192-198.

6. Glick B. R. Using soil bacteria to facilitate phytoremediation // Biotechnology advances. 2010. Vol. 28. № 3. P. 367-374.

7. Yang J., Kloepper J.W., Ryu C.M. Rhizosphere bacteria help plants tolerate abiotic stress // Trends in plant science. 2009. Vol. 14. № 1. P. 1-4.

8. Mohite B. Isolation and characterization of indoleacetic acid (IAA) producing bacteria from rhizospheric soil and its effect on a plant growth // Journal of soil science and plant nutrition, 2013, Vol. 13. № 3, P. 638-649. 
9. Sukumar P., Legue V. , Vayssieres A. , Martin F., Tuskan G. A., Kalluri U. C. Involvement of auxin pathways in modulating root architecture during beneficial plant-microorganism interactions // Plant, cell \& environment. 2013. Vol. 36. № 5. P. 909-919.

10. Li W., Wang D., Hu F., Li H., Ma L., Xu L. Exogenous IAA treatment enhances phytoremediation of soil contaminated with phenanthrene by promoting soil enzyme activity and increasing microbial biomass // Environmental Science and Pollution Research. 2016. P. 1-9.

11. Alvarez-Lopez V., Prieto-Fernandez A., Janssen J., Herzig R., Vangronsveld J., Kidd P.S. Inoculation methods using Rhodococcus erythropolis strain P30 affects bacterial assisted phytoextraction capacity of Nicotiana tabacum // International journal of phytoremediation. 2016. Vol. 18. № 4. P. 406-415.

12. Cook R. L., Hesterberg D. Comparison of trees and grasses for rhizoremediation of petroleum hydrocarbons / /International journal of phytoremediation. 2013. Vol. 15. № 9. P. 844-860.

13. Liu W., Sun J., Ding L., Luo Y., Chen M., Tang C. Rhizobacteria (Pseudomonas sp. SB) assist phytoremediation of oily-sludge-contaminated soil by tall fescue (Testuca arundinacea L.) // Plant and soil. 2013. Vol. 371. № 1-2. P. 533-542.

14. Волченко Н.Н., Карасёва Э.В. Скрининг углеводородокисляющих бактерий-продуцентов поверхностноактивных веществ биологической природы и их применение в опыте по ремедиации нефтезагрязненной почвы и нефтешламма // Биотехнология. 2006. № 2. С. 57-62.

15. Худокормов А.А., Карасёва Э.В., Волченко Н.Н., Самков А.А., Козицын А.Е. Деструкция углеводородов различными морфотипами нефтеокисляющих актинобактерий // Политематический сетевой электронный научный журнал Кубанского государственного аграрного университета. 2013. № 92. С. 153-175.
16. Худокормов А.А., Карасёва Э.В., Самков А.А., Волченко Н.Н., Карасёв С.Г., Батина Е.В. Влияние источника углерода на устойчивость к тяжёлым металлам штаммов нефтеокисляющих актинобактерий, используемых в процессах биоремедиации // Политематический сетевой электронный научный журнал Кубанского государственного аграрного университета. 2012. № 83. С. 119-128.

17. Нетрусов А.И., Егорова М.А., Захарчук Л.М. Практикум по микробиологии. М.: Академия, 2005. 608 с.

18. Meudt W. J., Gaines T. P., Studies on the oxidation of indole-3-acetic acid by peroxidase Enzymes. Colorimetric Determination of Indole-3-Acetic Acid Oxidation Products // Plant Physiology. 1967. № 42. P. 13951399.

19. Whyte L.G., Slagman S.J., Pietrantonio F., Bourbonnière L., Koval S.F., Lawrence J.R., Inniss W.E., Greer C.W. Physiological adaptations involved in alkane assimilation at a low temperature by Rhodococcus sp. strain Q15 // Applied and environmental microbiology. 1999. Vol. 65. № 7. P. 2961-2968.

20. Sethia B., Mustafa M., Manohar S., Patil S. V., Jayamohan N. S., Kumudini B. S. Indole acetic acid production by fluorescent Pseudomonas spp. from the rhizosphere of Plectranthus amboinicus (Lour.) Spreng. and their variation in extragenic repetitive DNA sequences // Indian J. Exp. Biol. 2015. Vol. 53. P. 342-349.

21. Sokolovska I., Rozenberg R., Riez C., Rouxhet P.G., Agathos S.N., Wattiau P. Carbon source-induced modifications in the mycolic acid content and cell wall permeability of Rhodococcus erythropolis E1 // Applied and environmental microbiology. 2003. Vol. 69. № 12. P. 7019-7027.

22. Корягин Ю.В. Влияние биопрепаратов и микроэлементов на рост и развитие растений гороха // НТП: земледелие и растениеводство. 2009. № 5. C. 26-28.

\section{INFLUENCE OF TEMPERATURE AND CARBON SOURCES ON AUXIN BIOSYNTHESIS BY RHODOCOCCUS ERYTHROPOLIS STRAIN AND THEIR PHYTOSTIMULATING ACTIVITY IN URBANOZEM SOIL}

D.N. Otroshko, postgraduate student of the Chair of Genetics, Microbiology and Biotechnology

V.V. Sheremet, master student of Faculty of Biology

N.N. Volchenko, candidate of biological sciences, associate professor of the Chair of Genetics, Microbiology and Biotechnology

A.A. Khudokormov, candidate of biological sciences,

associate professor of the Chair of Genetics, Microbiology and Biotechnology

A.A. Samkov, candidate of biological sciences, lecturer of the Chair of Genetics, Microbiology and Biotechnology Kuban State University, Krasnodar (Russia)

Abstract. The aim of this research was to study the effect of temperature and carbon sources for synthesizing activity of Rhodococcus erythropolis VKM Ac-2017D strain on the mineral medium. Tryptophan at a concentration of $0,5 \mathrm{~g} / 1$ was added as a precursor for indole-3-acetic acid (IAA) biosynthesis. Phytostimulating effect was shown in condition of soil experiment using lawn grass mixture (Festuca rubra - 30\%, Lolium perenne - 30\%, Poa pratensis $20 \%$, Festuca rubra trichlorophylla - 15\%, Festuca ovina - 5\%). The strain of selected oil-degrading bacteria was able to produce IAA on both hydrocarbon and carbohydrates as carbon sources. The differences were found in the production of auxin that depended on temperature and types of $\mathrm{C}$-substrate. When sucrose used as a carbon source the maximum in production of IAA was $34,3 \mu \mathrm{g} / \mathrm{ml}$ at the temperature of $15^{\circ} \mathrm{C}$. When culturing microorganisms on hexadecane the highest concentration IAA $(77,69 \mu \mathrm{g} / \mathrm{ml})$ was achieved at $25^{\circ} \mathrm{C}$. The culture broth (supernatant) and native bacterial suspension had shown phytostimulating activity on the lawn grass (weight of plant biomass, germination) to compare to water and chemically synthesized IAA in condition of soil experiment.

Keywords: Indole-3-acetic acid (IAA); plant-microbial interaction; oil-degrading bacteria; Rhodococcus erythropolis; plant growth-promoting bacteria (PGPB); rhizosphere; plant germination; phytostimulating; rhizoremediation; ecological microbiology and biotechnology. 